\title{
Dissolution Rates of Calcium Boluses and Their Effects on Serum Calcium in Dairy Cattle [Corrigendum]
}

Verhoef W, Zuidhof S, Ralston B, Ross JA, Olson M. Vet Med (Auckl). 2021;12:23-32

Page 24, Materials and Methods, In vivo Dissolution Rates of Commercial Calcium Boluses section, 1st sentence, “........ Bolus 2 (intermediate calcium chloride, intermediate calcium carbonate bolus): 176-g Bolus supplying $39.0 \mathrm{~g}$ of calcium from $106.9 \mathrm{~g}$ of calcium chloride, $4.5 \mathrm{~g}$ of calcium propionate, and $22.3 \mathrm{~g}$ of calcium carbonate (Transition Bolus, Vetoquinol N.-A Inc, Lavaltrie, Quebec, Canada); and Bolus 3 (low calcium chloride, high calcium carbonate bolus): 206-g Bolus supplying $54 \mathrm{~g}$ of calcium from ......." should read "........ Bolus 2 (intermediate calcium chloride, intermediate calcium carbonate bolus): 176-g Bolus supplying $44.0 \mathrm{~g}$ of calcium from $106.9 \mathrm{~g}$ of calcium chloride, $4.5 \mathrm{~g}$ of calcium propionate, and $22.3 \mathrm{~g}$ of calcium carbonate (Transition Bolus, Vetoquinol N.-A Inc, Lavaltrie, Quebec, Canada); and Bolus 3 (low calcium chloride, high calcium carbonate bolus): 206-g Bolus supplying $50 \mathrm{~g}$ of calcium from .......”.

Page 25, Table 1, the data for Vitamin D and Total $\mathrm{Ca}^{2+}$ rows were incorrect due to oversight of authors during the revision and editing stage.
The correct Table 1 is as follows:

Table I Composition of the Commercially Available Boluses Used in This Study

\begin{tabular}{|c|c|c|c|}
\hline \multirow[t]{2}{*}{ Component } & \multicolumn{3}{|c|}{ Content (g) per bolus } \\
\hline & $\begin{array}{l}\text { Cal-Boost } \\
\text { (Bolus I) }\end{array}$ & $\begin{array}{l}\text { Transition } \\
\text { (Bolus 2) }\end{array}$ & $\begin{array}{c}\text { RumiLifeCal24 } \\
\text { (Bolus 3) }\end{array}$ \\
\hline Calcium Chloride $^{a}$ & 112.0 & 106.9 & 92.16 \\
\hline Calcium Sulfate & 53.6 & & \\
\hline Calcium Carbonate & & 22.26 & 72.76 \\
\hline Calcium Propionate & & 4.48 & \\
\hline Magnesium Oxide & & & 4.72 \\
\hline Vitamin D & 0.00125 & 0.00125 & 0.001 \\
\hline Total $\mathrm{Ca}^{2+}$ & 43.0 & 44.0 & 50.0 \\
\hline Rapidly Available $\mathrm{Ca}^{2+}$ & 43.0 & 39.6 & 33.3 \\
\hline Coating & Yes $(x 2)$ & Yes & Yes \\
\hline
\end{tabular}

Notes: ${ }^{a} \mathrm{Cal}$-boost uses calcium chloride dihydrate; Transition and RumiLifeCal24 use anhydrous calcium chloride.

The authors apologize for this error.

\section{Publish your work in this journal}

Veterinary Medicine: Research and Reports is an international, peerreviewed, open access journal publishing original research, case reports, editorials, reviews and commentaries on all areas of veterinary medicine. The manuscript management system is completely online and includes a very quick and fair peer-review system. Visit http://www.dovepress.com/testimonials.php to read real quotes from published authors. 